\title{
Training of special teachers to use the resources of Moscow E-School
}

\author{
Yulia A. Afanasyeva ${ }^{1 *}$, Elena G. Gravitskaya ${ }^{1}$, Galina V. Paramonova ${ }^{1}$, Olga I. Gromova ${ }^{1}$, \\ and Sholpan A. Bulekbayeva ${ }^{2}$ \\ ${ }^{1}$ Moscow City University, Institute of Special Education and Psychology, Department of Special \\ Pedagogy and Comprehensive Rehabilitation, Moscow, Russia \\ ${ }^{2}$ National Children's Rehabilitation Center of Corporate Fund "University Medical Center", \\ Nursultan, Republic of Kazakhstan
}

\begin{abstract}
This article discusses the issues of training special teachers for using modern digital educational technologies, in particular innovation resources of Moscow E-School (MES). The aim of this work is in development of technology of specialists' training, capable to work with the resources of MES, in the frames of higher education. The following research methods were applied: surveying students, expert appraisal of students by teachers, aiming at formed skills and habits to work in MES environment. The obtained experimental results evidence that in the frames of higher education, the proposed technology of specialists' training, capable to work with the resources of MES in the frames of optional courses, demonstrated sufficiently high results. The study revealed high satisfaction of teachers with the level of students' qualification, namely: creative potential was enhanced, during the practice the students demonstrated higher involvement. Thus, in 2020, the teachers supervising the practice marked high level of skills of operation with MES resources demonstrated by $57 \%$ of students, which was nearly by two times higher than in 2018 (31\%). In 2020, the average level was recorded for $28 \%$ of students, the low level - for $15 \%$ of students, which was nearly by two times lower than in 2018 (27\%). Introduction of such optional course is exclusive, since it is oriented at training students specializing in special (defectology) education and solves the following tasks: firstly, to arm with the skills and habits of operation in digital environment, namely, MES, and secondly, to arm with specific knowledge and skills of development of electronic content for disabled children.
\end{abstract}

Keywords: Moscow E-School, digitalization of education, disabled children, children with peculiar educational demands.

\section{Introduction}

One of the prioritized trends of modern education system is informatization of secondary school and higher university. The use of information and communication technologies (ICT)

* Corresponding author: afanasievaja@mgpu.ru 
in learning transforms conventional educational environment, provides person-centered approach in teaching school subjects, allows for students to find quickly the required data in huge information flow, improves motivation to learning [1-3].

The existing pedagogical science considers digital resources as efficient forms of learning at all stages of lifecycle. Methodological grounds of these resources are presented by the concepts of dialogical and interactive approaches $[4,5]$. Teachers and supporting experts (speech therapists, psychologists) are able to create environment, which allows for disabled pupils to construct own concepts of ambient world. Such environment consists of ICT, using which any pupil finds own area of acquired experience [6, 7].

A new educational resource of unified digital environment for organization of learning process irrespective of place and time is presented by Moscow E-School (MES) [8-11].

MES assumes the use of multifunctional interactive whiteboard instead of standard blackboard for learning, as well as tablets of students and teacher [10-12].

The MES system is actively used also for remedial education. Disabled children, while studying in inclusive schools, can use the opportunities of MES both during learning of main component of adapted educational program and during studies with special teacher, speech therapist, psychologist [13-15]

Involvement of MES resources into education of disabled persons allows to apply ICT as a bypass for achievement of maximum compensation of deviation; solution to the problems of remedial and developing purposes, as well as for didactic and communication tasks. Therefore, the problem of students' training becomes especially important as they need to be familiar with the skills of operation with MES resources and development of educational content of MES for disabled persons [13-16].

Creation of interactive content in the system of MES and its use for education of disabled children requires from a teacher the knowledge of general technology of operation with MES platform and specificity of its use for each category of children (nosological group), as well as specificity of remedial education of such children.

While teaching disabled children, teachers and speech therapists should be familiar with the specificity of their application so that, on the one hand, the education would be carried out with application of modern innovation technologies, and, on the other hand, would not impair the health of children $[13,14]$.

Taking into account the importance of the problem, we formulated the following objective: to develop training technology of specialist familiar with resources of MES in the frames of higher education.

\section{Methods}

The research methods were as follows: statistical analysis of implementation of MES platform in Moscow, students' surveying, expert appraisal of students by teachers aiming at estimation of formed skills and habits of operation in MES environment.

\section{Results}

Statistical analysis of implementation of MES platform in Moscow based on quantitative data evidences high rates of technical provision with the resources of MES in educational entities.

Quantitative data on technical equipment of Moscow educational entities with the MES resources (notebooks, servers, Wi-Fi, interactive whiteboards) in 2020 are at stage of collection and processing; however, it is summarized in the table that in the plans of 2019, the "notebook" positions were fulfilled $(38,917$ units were in the plan, 40,000 units were installed in 2019), i.e. the schools were completely equipped with notebooks, equipment of 
schools with interactive whiteboards was nearly completed (20,331 units were in the plan, 19,000 units were available in 2019). While analyzing the rates of technical provision, it is possible to state that the plan of technical provision of Moscow schools with the MES resources will be fulfilled in 2020 .

Dynamics of involvement of disabled children evidences increase in the number of disabled pupils involved in education using the resources of MES: in 2019, 81\% of pupils studied in internal study mode, in 2017 - only 7\% of pupils; in 2019, 87\% of pupils studied in the frames of home education, in 2017 - only $2 \%$ of pupils.

Moscow City University has been training specialists to use the resources of MES for education of pupils with peculiar educational demands since 2018.

Table 4. Dynamics of use of MES resources during school practice (\%)

\begin{tabular}{|c|c|c|c|}
\hline Number of students & $\mathbf{2 0 1 8}$ & $\mathbf{2 0 1 9}$ & $\mathbf{2 0 2 0}$ \\
\hline using the MES resources in practice & 45 & 52 & 78 \\
\hline using ready lesson scenarios from MES library & 22 & 24 & 17 \\
\hline using lesson scenarios from MES library with high rating & 54 & 65 & 77 \\
\hline using own lesson scenarios & 14 & 48 & 64 \\
\hline adapting the content to requirements of teaching disabled children & 43 & 76 & 89 \\
\hline
\end{tabular}

In $2020,78 \%$ of students in the course of school practice in the entities of Moscow used the MES resources. Among ready scenarios, the students preferred scenarios with high ratings, which evidenced professional and sincere approach upon selection of scenarios. Increase in the fraction of high-rated lessons is a consequence of progressive filling of MES library and improved quality; hence, their frequency of use also increased. In the course of years, the students demonstrated the following use of lesson scenarios with high ratings from the MES library: $54 \%, 65 \%$, and $77 \%$.

However, the MES library has insufficient materials adapted to requirements of education of disabled children, therefore, the students, using the acquired knowledge, independently and with assistance of practice supervisors, add modifications to the content according to the requirements of education of disabled children. If at the beginning of implementation of MES program the students demonstrated moderate orientation to peculiar demands of disabled pupils (43\%), then upon development of adapted courses and understanding of structure of contents, the students began to more actively apply the special knowledge in presentation of learning materials using electronic lessons (76\% in 2019 and $89 \%$ in 2020).

A very important point was the fact of ability to adapt ready scenario for peculiar educational demands of disabled children: to make text and illustrative material accessible, to adapt interactive and test assignments, to select accessible video and audio content.

According to the survey results, from year to year the students more easily cope with preparing electronic lesson scenarios, since the fraction of Internet technologies in programmed learning increases (both in secondary school and university) together with the increase in atomic content (images, video and audio records) in the MES library (Fig. 1). 


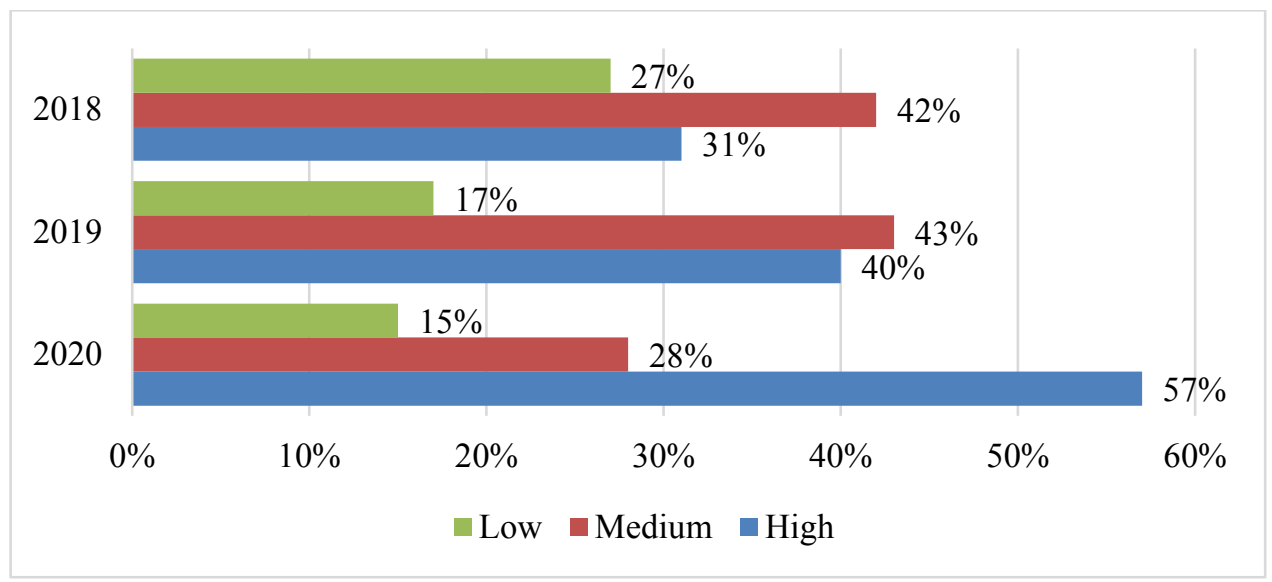

Fig. 1. Expert appraisal of students' skills to operate with the MES resources during school practice

Thus, in 2020, the teachers supervising the practice marked high level of skills of operation with MES resources demonstrated by $57 \%$ of students, which was nearly by two times higher than in 2018 (31\%). In 2020, the average level was recorded for $28 \%$ of students, the low level - for $15 \%$ of students, which was nearly by two times lower than in $2018(27 \%)$.

The surveying revealed high satisfaction of teachers with the level of students' qualification, namely: creative potential was enhanced, during the practice the students demonstrated higher involvement. In particular, it was observed in independent approach of students to adaptation of their lessons to peculiar educational demands of mentally disabled pupils, in correct time alternation of operation work with interactive whiteboard.

\section{Discussion}

In September 2019, the academic plan was supplemented by the optional course for students titled "Technology of development and use of resources of MES for pupils with peculiar educational demands". The optional course is scheduled for one semester, it is estimated in two credits, contains detailed developed practical classes, during which not only theoretical knowledge is presented but also practical skills and habits are developed aimed at development of interactive lesson scenario in MES environment.

The optional course includes such sections as "Specificity of the use of MES resources for children with peculiar educational demands", "Introduction into the environment of MES", "Creation of e-lesson template", "Creation of slide show", "Using audio and video records", "Using hyperlinks", "Creation of interactive assignments", "Creation of test assignment", "Using assignments similar to the format of international and national studies of education quality". The students during practical studies in computer class with Internet connection are proposed to create content for fragments of lesson scenario at first of reproductive pattern, that is, to reproduce the proposed, and then of creative pattern. During development of the content at creative level, a student independently develops assignment for pupils, makes questions for children, selects illustrative material, arranges the material, solves the issue of assignment design.

Introduction of such optional course is exclusive, since it is oriented at training students specializing in special (defectology) education and solves the following tasks: firstly, to arm with the skills and habits of operation in digital environment, namely, MES, and secondly, to arm with specific knowledge and skills of development of electronic content for disabled children. 


\section{Conclusion}

In the frames of higher education, the proposed technology of specialists' training, capable to work with the resources of MES in the frames of optional courses, demonstrated sufficiently high results. The study revealed high satisfaction of teachers with the level of students' qualification, namely: creative potential was enhanced, during the practice the students demonstrated higher involvement. In particular, it was observed in independent approach of students to adaptation of their lessons to peculiar educational demands of mentally disabled pupils, in correct time alternation of operation work with interactive whiteboard. Thus, in 2020, the teachers supervising the practice marked high level of skills of operation with MES resources demonstrated by $57 \%$ of students, which was nearly by two times higher than in 2018 (31\%). In 2020, the average level was recorded for $28 \%$ of students, the low level - for $15 \%$ of students, which was nearly by two times lower than in $2018(27 \%)$.

\section{References}

1. L.M. Castro Benavides, J.A.T. Arias, M.D. A. Serna, J. W. B. Bedoya, D. Burgos, Sensors, 20(11) 3291 (2020) https://doi.org/10.3390/s20113291

2. R.D. Sousa, B. Karimova, S. Gorlov, E3S Web of Conferences, 159, 09014 (2020). https://doi.org/10.1051/e3sconf/202015909014

3. E.V. Frolova, O.V. Rogach, T.M. Ryabova, European Journal of Contemporary Education, 9(2), 313-336 (2020)

4. V.A. Krivova, Izvestiya instituta pedagogiki i psikhologii obrazovaniya, 3, 25-30 (2017)

5. O.N. Machekhina, Espacios, 38(40), 26 (2017)

6. M.Y. Aksenova, E.F. Miftyakova, Pedagogicheskiye Vozmozhnosti InformatsionnoKommunikatsionnykh Tekhnologiy Na Urokakh Geografii [Pedagogical opportunities of information and communication technologies at lessons of geography], in Collection of articles of the International Scientific and Practical Conference "XL" Mezhdunarodnyye Nauchnyye Chteniya (Pamyati A. I. Notkina)" [XL International Scientific Readings (In Memory of A.I. Notkin)], 16 December 2018, Moscow, Russia (2018)

7. E. Head, British Journal of Sociology of Education, 41(5), 593-607 (2020). https://doi.org/10.1080/01425692.2020.1776594

8. T. N. Antonova, Professionalnoye obrazovaniye. Stolitsa, 1, 32-34 (2018)

9. V. V. Grinshkun, I. M. Remorenko, Informatics and Education, 7(286), 3-8 (2017)

10. E.V. Frolova, T.M. Ryabova, O.V. Rogach, European Journal of Contemporary Education, 8(4), 779-789 (2019)

11. V.V. Grinshkun, N.A. Usova, Journal of Siberian Federal University - Humanities and Social Sciences, 12(9), 1622-1634 (2019)

12. Y.V. Kemeris, Professionalnoye obrazovaniye i obshchestvo, 2(22), 283-284 (2017)

13. Y.A. Afanasyeva, Aktualnyye voprosy nauki, 46, 103-107 (2018)

14. O.I. Kukushkina, Defectology, 2, 72 (2002)

15. Y.N. Soroko, Spetsyyalnaya adukatsya, 1, 26-30 (2014)

16. I.Y. Levchenko, I.V. Evtushenko, I.A. Nikolskaya, Distance education: the teacher about schoolchildren with disabilities (Natsionalnyy knizhnyy tsentr, Moscow, 2013) 
17. UNESCO Institute for Information Technologies in Education, Informatsionnyye i kommunikatsionnyye tekhnologii dlya lyudey s narusheniyami zreniya [Information and communication technologies for people with visual impairments] (Rehacomp, Moscow, 2012) 